\title{
EFFECT OF RECYCLING OF ELEMENTAL CHLORINE FREE BLEACHING EFFLUENT TREATED BY ELECTROCOAGULATION ON PAPER PROPERTIES
}

\author{
QASEEM HAIDER, DUSHYANT KUMAR and CHHAYA SHARMA \\ Environmental Research Laboratory, Department of Paper Technology, \\ Indian Institute of Technology, Roorkee, Saharanpur Campus, \\ Saharanpur, Uttar Pradesh, 247001, India \\ \Corresponding author: Chhaya Sharma, chhaya1964@rediffmail.com
}

Received March 4, 2021

This study aimed to determine the effect of recycling elemental chlorine free (ECF) bleaching effluent $\left(\mathrm{D}_{0} \mathrm{E}_{\mathrm{p}} \mathrm{D}_{1}\right.$ and $\mathrm{OD}_{0} \mathrm{E}_{\mathrm{p}} \mathrm{D}_{1}$ ) after treatment through electrocoagulation under optimum conditions on paper properties. The effect of $\mathrm{pH}$, current density, time and dose of electrolyte on the reduction of chemical oxygen demand (COD) and color was studied. Maximum decrease in COD and color was found under optimum conditions (i.e., $\mathrm{pH} 7$, treatment time of 30 min, current density of $29.16 \mathrm{~mA} / \mathrm{cm}^{2}$, and $1 \mathrm{~g} / \mathrm{L} \mathrm{NaCl}$ ). Under these optimum conditions, the reduction in COD and color was of $79.9 \%$ and $99.10 \%$, respectively. The reduction in the strength properties of paper, caused by recycling, was found to be insignificant, but a decline of $2.11 \%$ for $\mathrm{D}_{0} \mathrm{E}_{\mathrm{p}} \mathrm{D}_{1}$ and of $1.43 \%$ for $\mathrm{OD}_{0} \mathrm{E}_{\mathrm{p}} \mathrm{D}_{1}$ in brightness was found. Using the electrocoagulation method to treat the bleaching effluent can prove to have valuable potential towards wastewater utilization, pollution control, and sustainable development of the industry.

Keywords: ECF bleaching, bleaching effluent, electrocoagulation, COD and color, paper properties, Stainless Steel-304 (SS-304)

\section{INTRODUCTION}

The pulp and paper industry is one of the prime sources of pollution, which discharges a considerable amount of hazardous waste into the environment. ${ }^{1,2}$ It has ranked third after the metal and chemical industry in water-intensive processes. ${ }^{3}$ The water consumption and discharge scenarios of Indian paper industries are very far from the international standards. Indian industries use $30-120 \mathrm{~m}^{3}$ fresh water per ton of paper production and generate a considerable effluent. ${ }^{4,5}$ The effectiveness of papermaking may change the characteristics of the effluent generated. Highly toxic and colored effluents discharged into the environment cause serious problems, disturbing aquatic life and causing water-borne diseases and bioaccumulation. ${ }^{3,6}$ Because of the many environmental problems like depletion of groundwater level and reduction in rainfall, on the one hand, and the huge demand of water by various water-intensive industries, on the other hand, the Central Pollution Control Board (CPCB) has pressurized the industries to rethink the management of bleach plant effluents to save the environment. ${ }^{3}$ The characteristics of generated wastewater depend upon kappa number, target brightness, viscosity, and other parameters considered during pulping and papermaking. It is essential to know the effluent characteristics for selecting the treatment process that can make it suitable for reuse in the same industry. The characteristics and quantity of wastewater discharged by the paper industry should be according to the CPCB discharge standard.

Paper manufacturing is a complex process that involves various steps: raw material preparation, pulping, bleaching, stock preparation (fiber shortening, fibrillation, addition of functional and process additives), forming, pressing, coating, drying, etc. Before pulping, chipping of wood is done in the raw material preparation section. Then, chips are transferred for pulping. The pulping process involves breaking of the wood structure and separation of fibers from the cemented material called lignin., ${ }^{7,8}$ In the 
bleaching section, pulp bleaching is done with the help of various chemicals, such as oxygen, chlorine, hydrogen peroxide, liquid chlorine dioxide, etc. ${ }^{9,10}$ Then, the pulp is transferred to the paper making section. The dirt, fibers, solid, etc., present in the wastewater generated from the raw material preparation section is filtered, and the filtrate is sent back to the same section for reuse. ${ }^{3}$ Black liquor is the effluent that is generated from the pulping section and it contains cooking chemicals, lignin, resins, and other extractives. The black liquor from the pulping section is then transferred to the recovery section to recover the chemicals and energy. The effluent generated from the bleaching section contains adsorbable organic halides (AOX), organic compounds, color and many more. Inorganic dyes, organic compounds and particulate matter are present in wastewater from the papermaking section. ${ }^{3}$

Residual lignin in the pulp is responsible for color absorption and color reversion of the paper. ${ }^{11,12}$ The bleaching is done to gain the desired brightness level of the pulp. ${ }^{13}$ Bleaching is a continuous process in which washing of pulp is done after each stage of bleaching. In this study, two ECF bleaching sequences have been used, i.e., $\mathrm{OD}_{0} \mathrm{E}_{\mathrm{p}} \mathrm{D}_{1}$ and $\mathrm{D}_{0} \mathrm{E}_{\mathrm{p}} \mathrm{D}_{1}$, as these sequences are used by most of the pulp and paper mills in India. ${ }^{4}$ Here, $\mathrm{O}$ indicates oxygen bleaching, $\mathrm{D}_{0}$ - first chlorine dioxide, $\mathrm{E}_{\mathrm{p}}$ - alkali extraction followed by peroxide, and $\mathrm{D}_{1}$ - second chlorine dioxide stage. Since a large volume of wastewater is generated from the bleaching section, it contains highly toxic substances that cannot be directly discharged into the environment without adequate treatment. On the other hand, the treatment of wastewater by chemical and physical processes has limitations because of the generation of a considerable amount of sludge, additional chemical requirement, and partial removal of organic chemicals from wastewater. ${ }^{14,15}$

In Indian paper industries, physical and chemical techniques are generally used for wastewater treatment. The physical technique involves sedimentation, adsorption, ultrafiltration, nanofiltration, and osmosis. The chemical technique involves neutralization, peroxidation, photocatalysis, and supercritical water oxidation. Moreover, biodegradation is a biological technique, an economical process that requires some specific environmental conditions. In the case of anaerobic degradation, long retention time and acclimation are required. Unfortunately, the biochemical method cannot be used because of the low biodegradability index of wastewater caused by the presence of lignin., ${ }^{7,14-16}$

Because of the issues discussed above, as well as others not mentioned here, we used electrocoagulation to overcome the limitations of other methods and technologies to treat bleach plant effluent. Among all the electrochemical processes, electrocoagulation gives the best results due to complete pollutant degradation, removal of color, and less sludge generation. Along with being complex, electrocoagulation is an interdependent process, in which dissolution of the anode as a sacrificial electrode occurs in situ. ${ }^{17}$ Coagulants are generated in the aqueous phase. Due to the coagulant species, the suspended particles are precipitated and the dissolved contaminants are adsorbed. ${ }^{7,18}$ According to the literature, most of the work has been done on black liquor treatment through an electrochemical process. Limited work regarding the treatment of bleach plant effluent has been reported so far; thus, an effort has been made to find out the effect of different operating parameters, such as $\mathrm{pH}$, current density, time, and electrolyte dose, on COD and color reduction. Wastewater was treated under optimum conditions and used as wash water after the bleaching stages to check the recycling probability of treated wastewater and its effect on paper properties. In the bleaching process of pulp, elemental chlorine has been replaced by chlorine dioxide considering its environmental impact and selectivity towards chromophoric groups, with a minimum compromise of strength properties. ${ }^{1,19}$ This work would be instructive in opening a new path for making the pulp and paper industry environmentally friendly and sustainable.

\section{EXPERIMENTAL \\ Materials}

The chemicals used in this experiment were the following: $\mathrm{ClO}_{3}^{-}, \mathrm{NaOH}$ pellets, $\mathrm{H}_{2} \mathrm{O}_{2}, \mathrm{~K}_{2} \mathrm{Cr}_{2} \mathrm{O}_{7}$, $\mathrm{H}_{2} \mathrm{SO}_{4}$ and $\mathrm{NaCl}$. The materials and equipment used in the study included: Teflon tape, polythene bags, beakers of different capacities, filter paper, funnel, measuring cylinder, pipette, burette, distilled water, thermometer, digester at $160{ }^{\circ} \mathrm{C}$, oxygen cylinder, DC supply, magnetic stirrer, electrodes, electrode holder, $\mathrm{pH}$ meter, hot plate, PFI mills, sheet former, press, glaze plates, drying ring, blotter papers, couch roll, couch plate, hot water bath, disintegrator, digital weighing machine, UV-visible spectrophotometer, tensile tester, burst tester, tear tester, folding endurance tester, Cobb tester, and refrigerator at $4{ }^{\circ} \mathrm{C}$. 


\section{Methods}

\section{Effluent collection and various bleaching stages}

The effluent used in this experiment was collected at a lab-scale by performing the bleaching of mixed unbleached hardwood pulp taken from a nearby paper mill. Bleaching is performed to increase pulp brightness either by removing or converting the colorcausing substances into non-color-causing substances. In this experiment, we used ECF bleaching to meet the target brightness (80-85\% ISO) of pulp. The formation of dioxins and dioxin-like compounds did not occur in considerable amounts as elemental chlorine is not used in the ECF bleaching process. ${ }^{20} \mathrm{We}$ used two ECF bleaching sequences, i.e., $\mathrm{D}_{0} \mathrm{E}_{\mathrm{p}} \mathrm{D}_{1}$ and $\mathrm{OD}_{0} \mathrm{E}_{\mathrm{p}} \mathrm{D}_{1}$. 100$200 \mathrm{~g}$ of unbleached oven-dried (OD) pulp was used for each bleaching sequence. After each stage of the bleaching sequences $\mathrm{D}_{0} \mathrm{E}_{\mathrm{p}} \mathrm{D}_{1}$ and $\mathrm{OD}_{0} \mathrm{E}_{\mathrm{p}} \mathrm{D}_{1}$, the pulp was washed with fresh water. The effluent that was generated was collected and stored at $4{ }^{\circ} \mathrm{C}$ for further testing and treatment by using the electrocoagulation process. The effluent that was obtained after the electrocoagulation treatment under optimum conditions was used to wash the pulp after every bleaching stage of similar sequences indicated by RC$\mathrm{D}_{0} \mathrm{E}_{\mathrm{p}} \mathrm{D}_{1}$ and $\mathrm{RC}-\mathrm{OD}_{0} \mathrm{E}_{\mathrm{p}} \mathrm{D}_{1}$. The bleaching conditions used are given in Tables 1 and 2.

\section{$O D_{0} E_{p} D_{1}$}

Oxygen stage $(\mathrm{O})$ : An oxygen bleaching reactor was used for oxygen bleaching of pulp. $200 \mathrm{~g}$ ovendried (OD) pulp of mixed hardwood was fed into a Continuous Stirrer tank Reactor (CSR). The reactor's conditions were as follows: consistency $8 \%$, oxygen pressure $5 \mathrm{Kg} / \mathrm{cm}^{2}$, temperature $90{ }^{\circ} \mathrm{C}, \mathrm{NaOH} 1.5 \%$, $\mathrm{pH} 11.5$, and time $60 \mathrm{~min}$. After adding all the chemicals, the pressure of oxygen was maintained in the reactor using a compressor for $60 \mathrm{~min}$. The command for intermediate mixing of the pulp in the reactor was given through the control system. On completion, the reactor was brought to room temperature, and the pulp was removed for washing using freshwater before further processing. All the effluent that was generated was collected and stored at a temperature of $4{ }^{\circ} \mathrm{C}$.

Table 1

Bleaching conditions for $\mathrm{D}_{0} \mathrm{E}_{\mathrm{p}} \mathrm{D}_{1}$ and $\mathrm{RC}-\mathrm{D}_{0} \mathrm{E}_{\mathrm{p}} \mathrm{D}_{1}$ sequences

\begin{tabular}{lcccccc}
\hline \multirow{2}{*}{ Parameter } & \multicolumn{3}{c}{$\mathrm{D}_{0} \mathrm{E}_{\mathrm{p}} \mathrm{D}_{1}$} & \multicolumn{3}{c}{$\mathrm{RC}-\mathrm{D}_{0} \mathrm{E}_{\mathrm{p}} \mathrm{D}_{1}$} \\
\cline { 2 - 7 } & $\mathrm{D}_{0}$ & $\mathrm{E}_{\mathrm{p}}$ & $\mathrm{D}_{1}$ & $\mathrm{D}_{0}$ & $\mathrm{E}_{\mathrm{p}}$ & $\mathrm{D}_{1}$ \\
\hline Kappa no. & 17 & - & - & 17 & - & - \\
Kappa factor & 0.26 & - & 2.63 & 0.27 & - & 2.63 \\
Bleach chemical (\%) & 4.42 & - & 1.5 & 4.59 & - & 1.5 \\
$\mathrm{NaOH}(\%)$ & - & 1.4 & - & - & 1.4 & - \\
$\mathrm{H}_{2} \mathrm{O}_{2}(\%)$ & - & 1.25 & - & - & 1.25 & - \\
$\mathrm{Consistency}(\%)$ & 5 & 10 & 5 & 5 & 10 & 5 \\
Initial pH & 2 & 12 & 2.5 & 2 & 12 & 2.5 \\
End pH & 1.94 & 10.97 & 2.74 & 1.96 & 10.99 & 2.69 \\
Temperature $\left({ }^{\circ} \mathrm{C}\right)$ & 70 & 70 & 70 & 70 & 70 & 70 \\
Time (min) & 60 & 60 & 180 & 60 & 60 & 180 \\
\hline
\end{tabular}

Table 2

Bleaching conditions for $\mathrm{OD}_{0} \mathrm{E}_{\mathrm{p}} \mathrm{D}_{1}$ and $\mathrm{RC}-\mathrm{OD}_{0} \mathrm{E}_{\mathrm{p}} \mathrm{D}_{1}$ sequences

\begin{tabular}{lcccccccc}
\hline \multirow{2}{*}{ Parameter } & \multicolumn{4}{c}{$\mathrm{OD}_{0} \mathrm{E}_{\mathrm{p}} \mathrm{D}_{1}$} & \multicolumn{5}{c}{$\mathrm{RC}_{-} \mathrm{OD}_{0} \mathrm{E}_{\mathrm{p}} \mathrm{D}_{1}$} \\
\cline { 2 - 8 } & $\mathrm{O}$ & $\mathrm{D}_{0}$ & $\mathrm{E}_{\mathrm{p}}$ & $\mathrm{D}_{1}$ & $\mathrm{O}$ & $\mathrm{D}_{0}$ & $\mathrm{E}_{\mathrm{p}}$ & $\mathrm{D}_{1}$ \\
\hline Kappa no. & 17 & 9 & - & - & 17 & 9.4 & - & - \\
Kappa factor & - & 0.24 & - & 2.63 & - & 0.24 & - & 2.63 \\
Bleach chemical (\%) & - & 2.16 & - & 1 & - & 2.56 & - & 1 \\
$\mathrm{NaOH}(\%)$ & 1.5 & - & 1.15 & - & 1.5 & - & 1.4 & - \\
$\mathrm{H}_{2} \mathrm{O}_{2}(\%)$ & - & - & 1 & - & - & - & 1.25 & - \\
$\mathrm{O}_{2}$ pressure $\left(\mathrm{Kg} / \mathrm{cm}^{2}\right)$ & 5 & - & - & - & 5 & - & - & - \\
Consistency $(\%)$ & 8 & 5 & 10 & 5 & 8 & 5 & 10 & 5 \\
Initial pH & 11.5 & 2 & 12 & 2.5 & 11.8 & 2.1 & 12 & 2.5 \\
End pH & 10.95 & 1.94 & 11.38 & 2.74 & 11.3 & 2 & 10.94 & 2.87 \\
Temperature $\left({ }^{\circ} \mathrm{C}\right)$ & 90 & 70 & 70 & 70 & 90 & 70 & 70 & 70 \\
Time (min) & 60 & 60 & 60 & 180 & 60 & 60 & 60 & 180 \\
\hline
\end{tabular}

\section{$D_{0}$ (First chlorine dioxide) stage}

An amount of $100 \mathrm{~g}$ of pulp bleached by the oxygen stage was disintegrated for $5 \mathrm{~min}$ and placed in double polythene bags, along with bleach chemicals. The conditions maintained were as follows: $\mathrm{ClO}_{2}$ $2.16 \%$ of OD pulp, consistency $5 \%, \mathrm{pH} 2.0$ by using 
acid, temperature $70{ }^{\circ} \mathrm{C}$ and time $60 \mathrm{~min}$. The bags were closed after sufficient mixing, and were placed in a hot water bath for $60 \mathrm{~min}$. The pulp was mixed 4 times during $60 \mathrm{~min}$. After completion, the pulp was taken out from the plastic bags and washed using fresh water. The effluent generated was collected and stored at $4{ }^{\circ} \mathrm{C}$ for further processing.

$E_{p}$ (Alkaline extraction with hydrogen peroxide) stage

Washed pulp after the $\mathrm{D}_{0}$ stage was subjected to alkaline extraction, followed by hydrogen peroxide bleaching. $\mathrm{NaOH} 1.15 \%$ and $\mathrm{H}_{2} \mathrm{O}_{2} 1 \%$ of OD pulp were added, $\mathrm{pH} 12$ and $10 \%$ consistency were maintained. All the material was transferred to a double polythene bag, and after mixing, it was placed into a hot water bath at $70{ }^{\circ} \mathrm{C}$ for $60 \mathrm{~min}$. Intermediate stage mixing of the pulp followed. The bleached pulp was taken out from the hot water upon completion and fresh water was used for its washing. Similarly, the collection of effluent was performed and it was stored at a temperature of $4{ }^{\circ} \mathrm{C}$ for further treatment.

\section{$D_{1}$ (Second chlorine dioxide) stage}

A similar process was performed as in $\mathrm{D}_{0}$ stage. Bleached pulp after alkaline extraction was placed in double polythene bags, along with bleach chemicals. The conditions maintained were: $\mathrm{ClO}_{2} 1 \%$ of OD pulp, consistency $5 \%, \mathrm{pH} 2.5$ by using acid, temperature 70 ${ }^{\circ} \mathrm{C}$ and time $180 \mathrm{~min}$. The bags were closed, and after sufficient mixing, were placed in a hot water bath for $180 \mathrm{~min}$. The pulp was mixed 6 times during $180 \mathrm{~min}$. After completion of the time, the pulp was taken out from the plastic bags and washed using fresh water. Similarly, the effluent generated were collected and stored at $4{ }^{\circ} \mathrm{C}$ for further processing.

\section{$D_{0} E_{p} D_{1}$}

The experiment for the $\mathrm{D}_{0} \mathrm{E}_{\mathrm{p}} \mathrm{D}_{1}$ sequence was performed similarly to that of the $\mathrm{OD}_{0} \mathrm{E}_{\mathrm{p}} \mathrm{D}_{1}$ sequence. The conditions were the following:

$\mathrm{D}_{0}$ stage: $\mathrm{ClO}_{2} 4.42 \%$ of OD unbleached pulp, consistency $5 \%, \mathrm{pH} 2.0$, temperature $70{ }^{\circ} \mathrm{C}$ and time $60 \mathrm{~min}$;

$\mathrm{E}_{\mathrm{p}}$ stage: $\mathrm{NaOH} 1.4 \%$ and $\mathrm{H}_{2} \mathrm{O}_{2} \quad 1.25 \%$ of $\mathrm{OD}$ bleached pulp, consistency $10 \%, \mathrm{pH} 12.0$, temperature $70{ }^{\circ} \mathrm{C}$, and time $60 \mathrm{~min}$;

$\mathrm{D}_{1}$ stage: $\mathrm{ClO}_{2} 1.5 \%$ of $\mathrm{OD}$ bleached pulp, consistency $5 \%, \mathrm{pH} 2.5$, temperature $70{ }^{\circ} \mathrm{C}$ and time $180 \mathrm{~min}$.

\section{$R C-O D_{0} E_{p} D_{1}$}

The prefix RC is used to show the recycling stage. In this stage, treated water was used instead of fresh water, and experiments were carried out in the same way as in earlier sequences. The conditions were as follows:

O stage: unbleached pulp $200 \mathrm{~g} \mathrm{OD}, \mathrm{NaOH} 1.5 \%$ of OD unbleached pulp, oxygen pressure $5.0 \mathrm{Kg} / \mathrm{cm}^{2}$, consistency $8 \%$, pH 11.8 , temperature $90{ }^{\circ} \mathrm{C}$, and time
$60 \mathrm{~min}$;

$\mathrm{D}_{0}$ stage: $\mathrm{ClO}_{2} 2.56 \%$ of $\mathrm{OD}$ unbleached pulp, consistency $5 \%, \mathrm{pH} 2.0$, temperature $70{ }^{\circ} \mathrm{C}$ and time $60 \mathrm{~min}$;

$\mathrm{E}_{\mathrm{p}}$ stage: $\mathrm{NaOH} 1.4 \%$ and $\mathrm{H}_{2} \mathrm{O}_{2} 1.25 \%$ of $\mathrm{OD}$ bleached pulp, consistency $10 \%, \mathrm{pH} 12.0$, temperature $70{ }^{\circ} \mathrm{C}$, and time $60 \mathrm{~min}$;

$\mathrm{D}_{1}$ stage: $\mathrm{ClO}_{2} 1 \%$ of OD bleach pulp, consistency $5 \%, \mathrm{pH} 2.5$, temperature $70{ }^{\circ} \mathrm{C}$ and time $180 \mathrm{~min}$.

\section{$R C-D_{0} E_{p} D_{1}$}

$\mathrm{D}_{0}$ stage: $\mathrm{ClO}_{2} 4.59 \%$ of OD unbleached pulp, consistency $5 \%, \mathrm{pH} 2.0$, temperature $70{ }^{\circ} \mathrm{C}$ and time $60 \mathrm{~min}$

$\mathrm{E}_{\mathrm{p}}$ stage: $\mathrm{NaOH} 1.4 \%$ and $\mathrm{H}_{2} \mathrm{O}_{2} \quad 1.25 \%$ of $\mathrm{OD}$ bleached pulp, consistency $10 \%, \mathrm{pH} 12.0$, temperature $70{ }^{\circ} \mathrm{C}$, and time $60 \mathrm{~min}$.

$\mathrm{D}_{1}$ stage: $\mathrm{ClO}_{2} 1.5 \%$ of $\mathrm{OD}$ bleached pulp, consistency $5 \%, \mathrm{pH} 2.5$, temperature $70{ }^{\circ} \mathrm{C}$ and time $180 \mathrm{~min}$

\section{Electrocoagulation process}

A reactor with the capacity of $250 \mathrm{~mL}$ was used to carry out the electrocoagulation treatment of the effluent. Four Stainless Steel-304 (SS 304) electrodes, with an area of $6 \times 5 \mathrm{~cm}^{2}$ on each side, were used, while $24 \mathrm{~cm}^{2}$ was immersed in the effluent. For proper mixing of the effluent by smooth rotation of the magnetic bead, a gap of $1.0 \mathrm{~cm}$ was maintained between the electrodes and a gap of $1.5 \mathrm{~cm}$ was maintained from the bottom of the cell, respectively. ${ }^{21}$ $\mathrm{HCl}(15 \% \mathrm{w} / \mathrm{v})$ was used to wash the electrodes, followed by washing with water and drying them before each run. ${ }^{22}$ Stabilized power was supplied through a DC rectifier, fitted with a current meter and voltmeter to the electrodes.

It is considered that the suspended and dissolved particles are aggregated and precipitated due to the coagulant species. ${ }^{23,24}$ Oxidation takes place on the anode, and generation of iron hydroxide, $\mathrm{Fe}(\mathrm{OH})_{\mathrm{n}}, \mathrm{n}=2$ or 3 occurs. $^{24}$ The two main mechanisms that have been described in the literature for the generation of metal hydroxide are presented below. ${ }^{24-26}$ The setup used is shown in Figure 1.

Mechanism 1:

Anode: $4 \mathrm{Fe} \rightleftharpoons 4 \mathrm{Fe} 2++8 \mathrm{e}-$

$4 \mathrm{Fe} 2++10 \mathrm{H} 2 \mathrm{O}+\mathrm{O} 2 \rightleftharpoons 4 \mathrm{Fe}(\mathrm{OH}) 2+8 \mathrm{H}+$

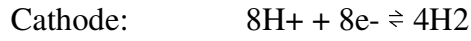

Overall: $4 \mathrm{Fe}(\mathrm{s})+10 \mathrm{H} 2 \mathrm{O}+\mathrm{O} 2 \gtrless 4 \mathrm{Fe}(\mathrm{OH}) 3(\mathrm{~s})+4 \mathrm{H} 2$

Mechanism 2:

Anode: $\mathrm{Fe} \rightleftharpoons \mathrm{Fe} 2++2 \mathrm{e}-$

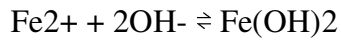

Cathode: $\quad 2 \mathrm{H} 2 \mathrm{O}+2 \mathrm{e}-\stackrel{2}{\mathrm{H} 2}+2 \mathrm{OH}-$

Overall: $\mathrm{Fe}+2 \mathrm{H} 2 \mathrm{O} \rightleftharpoons \mathrm{Fe}(\mathrm{OH}) 2(\mathrm{~s})+\mathrm{H} 2$

All the experiments were carried out at room temperature. For optimization of the treatment conditions, $250 \mathrm{~mL}$ of bleach effluent was fed into the reactor in each run and the parameters: $\mathrm{pH}$ (5 to 9), 
time (15 to 60 minutes), current density ( 7 to 35 $\left.\mathrm{mA} / \mathrm{cm}^{2}\right)$, and dose of electrolyte $(0.5$ to $2 \mathrm{~g} / \mathrm{L})$, were varied and the conditions for maximum reduction in COD and color were determined. The characteristics of the effluent are given in Table 3.

\section{Color determination}

To avoid the disturbance of suspended particles, samples were centrifuged, and $1 \mathrm{M} \mathrm{NaOH}$ solution was used to adjust the $\mathrm{pH}$ to 7 . A UV-visible spectrophotometer (SPEKOL 2000 Analytic Jena) was used to measure the UV absorbance at a wavelength of $465 \mathrm{~nm}^{27}$

\section{COD determination}

The open reflux method was used to determine the COD as per the American Public Health Association (APHA). Potassium dichromate and sulfuric acid were used to reflux the samples for $2 \mathrm{~h}$, and COD was calculated. ${ }^{28}$

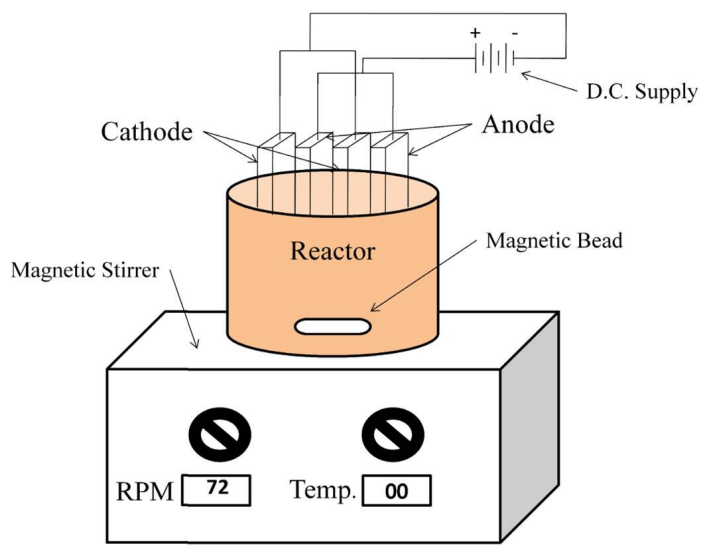

Figure 1: Schematic representation of the laboratory scale experimental setup for performing electrocoagulation

Table 3

Characteristics of the effluent

\begin{tabular}{lc}
\hline Characteristic & Value \\
\hline $\mathrm{pH}$ & 4.9 \\
$\mathrm{COD}(\mathrm{mg} / \mathrm{L})$ & 568 \\
$\mathrm{BOD}(\mathrm{mg} / \mathrm{L})$ & 143 \\
$\mathrm{TDS}(\mathrm{mg} / \mathrm{L})$ & 1656.82 \\
Color $(\mathrm{CU}(\mathrm{Pt}-\mathrm{Co}))$ & 0.25 \\
\hline
\end{tabular}

Preparation of paper handsheets using laboratory methods and testing of paper properties

Bleached pulp was first disintegrated for 2.5 minutes in a standard disintegrator, a consistency of $1 \%$ was maintained; the pulp was further disintegrated for $10 \mathrm{~min}$. Then, beating was done in an SS PFI mill under standard conditions, maintaining the consistency of $10 \% .^{29,30}$ The standard procedure was followed for preparing handsheets: handsheets of $200 \mathrm{~cm}^{2}$ area were made with the help of a laboratory sheet former of 20 L capacity, then, a sandwich of five sheets separated by polished plates and blotting paper were pressed with the help of a hydraulic press at a pressure of 5 $\mathrm{Kg} / \mathrm{cm}^{2}$. After separating the sheets from blotting paper, each polished plate with the sheet on it was fit into a drying ring for air drying. ${ }^{29}$ Kappa number was calculated through per-magnet consumption by the lignin present in the pulp, through the titration with sodium thiosulphate. ${ }^{31}$ The freeness (CSF) of the pulp was checked at a consistency of $0.2 \% .^{32}$ The strength properties determined were tensile index, tear index, burst index and folding endurance. ${ }^{33-35}$

\section{RESULTS AND DISCUSSION Effluent treatment by electrocoagulation}

The effects of operating parameters, such as $\mathrm{pH}$, treatment time, current density and electrolyte dose, on the efficiency of the treatment were determined to enhance the performance of the electrocoagulation process.

\section{Effect of $p H$}

The $\mathrm{pH}$ value was varied in the range from 5 to 9, while keeping all the other parameters constant, i.e., time $15 \mathrm{~min}$, current density 7.29 $\mathrm{mA} / \mathrm{cm}^{2}$, and electrolyte dose $0.5 \mathrm{~g} / \mathrm{L}$, as shown in Figure 2. The maximum reduction in COD and color was found at neutral $\mathrm{pH}$ 7. At low $\mathrm{pH}(\mathrm{pH}$ 
5), the efficiency of reducing COD was very low, because the majority of the iron was in the form of $\mathrm{Fe}^{2+}$, such as $\mathrm{Fe}(\mathrm{OH})_{2}{ }^{+}, \mathrm{Fe}(\mathrm{OH})^{2+}$, which are soluble species; hence it reduced the formation of coagulants. $^{36,37}$ The removal efficiency was increased from $\mathrm{pH} 5$ to 7 . The reduction was found maximum at $\mathrm{pH} 7$ because of shifting redox equilibrium to iron (III) ions in the monomeric form, such as $\mathrm{Fe}(\mathrm{OH})_{3}$, and in polyhydroxyl iron (III), such as $\mathrm{Fe}(\mathrm{OH})_{2}{ }^{+} \mathrm{Fe}\left(\mathrm{H}_{2} \mathrm{O}\right)_{5}(\mathrm{OH})_{2}{ }^{+}$and $\mathrm{Fe}\left(\mathrm{H}_{2} \mathrm{O}\right)_{4}(\mathrm{OH})^{2+}$, which are more reactive, as well as insoluble in nature, and make bonds with the pollutants that are present in the wastewater. ${ }^{38,39}$ COD reduction decreased from $\mathrm{pH} 7$ to 9 due to dissolution of $\mathrm{Fe}(\mathrm{OH})_{3}$, as well as generation of $\mathrm{Fe}(\mathrm{OH})_{4}{ }^{40}$ Due to hydrogen generation at the cathode, the end $\mathrm{pH}$ value was found to be more when the initial $\mathrm{pH}$ was less than $7 .^{41}$ Conversely, end $\mathrm{pH}$ was found to be less when initial $\mathrm{pH}$ was 8 to 9 , due to formation of $\mathrm{H}^{+}$near the anode and precipitation of $\mathrm{Ca}^{2+}$ and $\mathrm{Mg}^{2+}$ with metal positive ions. ${ }^{23,42}$ Values are given in Table 4.

\section{Effect of treatment time}

While keeping the $\mathrm{pH}$, current density and electrolyte dose fixed (i.e., $\mathrm{pH} 7$, current density $7.29 \mathrm{~mA} / \mathrm{cm}^{2}$, and electrolyte $0.5 \mathrm{~g} / \mathrm{L}$ ), the time was varied from $15 \mathrm{~min}$ to $60 \mathrm{~min}$. During the treatment, it was observed that the effluent gradually became darker and turned from transparent to opaque, as the reaction time increased. This can be explained by the generation of $\mathrm{Fe}(\mathrm{II})$ and $\mathrm{Fe}(\mathrm{III})$, which are responsible for color darkness during the treatment because of their green to yellowbrownish color, and the complex reaction occurring between $\mathrm{Fe}^{3+}, \mathrm{Fe}^{2+}$ and the polyphenol molecules, which generated a brown soluble compound. ${ }^{22,41}$ A $90.11 \%$ reduction in color was observed as the time of the treatment increased because most generated $\mathrm{Fe}$ ions combined with the pollutant species and settled down as sludge. 22,37 Similarly, as the treatment time increased, the COD levels were found to be reduced because the organic pollutants were adsorbed on the metal positive ion flocks formed in situ. ${ }^{37}$ COD removal of $46.98 \%$ was observed after $45 \mathrm{~min}$. No significant reduction was observed after 45 min of treatment, as shown in Figure 3, because of the generation of $\mathrm{Fe}$ (II) species, which reacted with dissolved oxygen in the effluent and reduced its amount. ${ }^{37}$ The optimum treatment time was taken as $30 \mathrm{~min}$.

\section{Effect of current density}

In the process of electrocoagulation, one of main factors responsible for the reaction rate of the reactor is current density. To study the effect of current density $\left(7.29-36.45 \mathrm{~mA} / \mathrm{cm}^{2}\right)$ on the reduction of COD levels and color of the effluent, the values of $\mathrm{pH}$, treatment time and electrolyte dose were fixed, i.e., $\mathrm{pH} \mathrm{7,} \mathrm{time} 30 \mathrm{~min}$, and electrolyte dose $0.5 \mathrm{~g} / \mathrm{L}$. With an increase in the values of current density, the reduction in COD and color also increased, as shown in Figure 4. The highest current density $\left(36.45 \mathrm{~mA} / \mathrm{cm}^{2}\right)$ provided the maximum reduction in $\mathrm{COD}$, since on increasing the current density, the bubble density was enhanced, along with a decrease in the size of bubbles, a greater upward flux, flocks growth leading to faster removal of pollutants from the effluent. ${ }^{43-45}$ However, there was no significant difference in COD reduction at current density levels from $29.16 \mathrm{~mA} / \mathrm{cm}^{2}$ to 36.45 $\mathrm{mA} / \mathrm{cm}^{2}$. A possible explanation may be the adsorption of lignin on the surface of the electrode, along with passivation formation due to the reaction occurring between the metal chloride and the magnesium and calcium salts, which results in a decrease in its activity. ${ }^{37,46}$ Color reduction becomes approximately constant beyond the current density of $21.87 \mathrm{~mA} / \mathrm{cm}^{2}$. The optimum value of $29.16 \mathrm{~mA} / \mathrm{cm}^{2}$ current density was chosen, as it allowed reaching a reduction in COD and color values of 76.99 and $98.93 \%$, respectively.

\section{Effect of electrolyte dose}

$\mathrm{COD}$ and color removal efficiency increased as $\mathrm{NaCl}$ dose was increased from 0.5 to $2 \mathrm{~g} / \mathrm{L}$, as shown in Figure 5. A maximum reduction of $99.11 \%$ in color at $1 \mathrm{~g} / \mathrm{L}$ and an $81.12 \%$ reduction in COD were observed at $1.5 \mathrm{~g} / \mathrm{L}$ electrolyte dose. Other parameters, such as $\mathrm{pH} 7$, current density of $29.16 \mathrm{~mA} / \mathrm{cm}^{2}$, and time of $30 \mathrm{~min}$, were fixed. Due to the presence of chloride in the solution, the anode generated $\mathrm{Cl}_{2}$, as well as $\mathrm{OCl}-$. OClremoves organic pollutants, as it is a strong oxidizing agent. Charge loading played a vital role in the treatment, because it not only causes an increase in conductivity, but also acts as a strong oxidizing agent, which results in a reduction in COD and color of the effluent. ${ }^{41,45,47}$ 


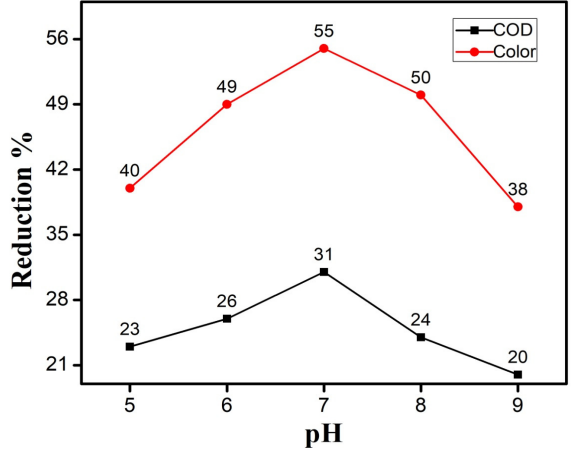

Figure 2: Effect of $\mathrm{pH}$ on COD and color reduction (conditions: time $15 \mathrm{~min}, \mathrm{CD} 7.29 \mathrm{~mA} / \mathrm{cm}^{2}$ and $\mathrm{NaCl}$ $0.5 \mathrm{~g} / \mathrm{L})$

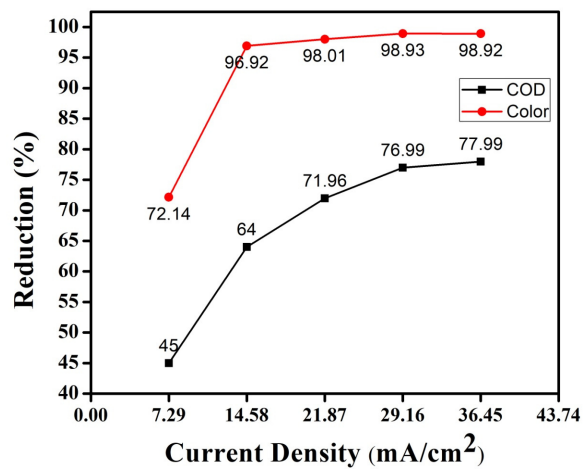

Figure 4: Effect of current density on COD and color reduction (conditions: $\mathrm{pH} 7$, time $30 \mathrm{~min}$, and $\mathrm{NaCl}$ $0.5 \mathrm{~g} / \mathrm{L})$

The effluent collected from each stage was mixed and analyzed for its characteristics. On analysis, COD $568 \mathrm{mg} / \mathrm{L}$, color 1224 PCU, BOD 143 $\mathrm{mg} / \mathrm{L}$, TDS $1656.82 \mathrm{mg} / \mathrm{L}$ and $\mathrm{BOD} / \mathrm{COD} 0.25$ were found. This mixed effluent was treated under optimum conditions ( $\mathrm{pH} 7$, CD 29.16 $\mathrm{mA} / \mathrm{cm}^{2}$, electrolyte $1 \mathrm{~g} / \mathrm{L}$, and time $30 \mathrm{~min}$ ).

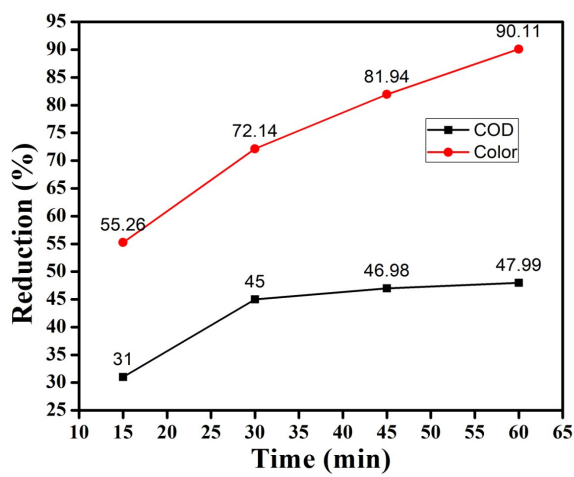

Figure 3: Effect of time on COD and color reduction (conditions: $\mathrm{pH} 7, \mathrm{CD} 7.29 \mathrm{~mA} / \mathrm{cm}^{2}$ and $\mathrm{NaCl} 0.5 \mathrm{~g} / \mathrm{L}$ )

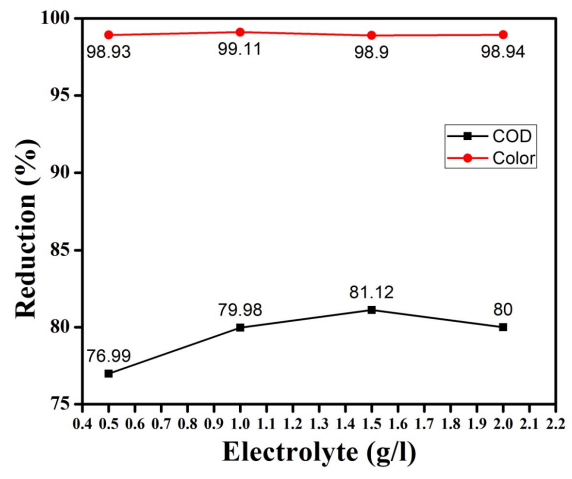

Figure 5: Effect of electrolyte dose on COD and color reduction (conditions: $\mathrm{pH} 7$, time $30 \mathrm{~min}$ and $\mathrm{CD}$ $29.16 \mathrm{~mA} / \mathrm{cm}^{2}$ )

Treated effluent was also collected and, on characterization, COD $114 \mathrm{mg} / \mathrm{L}$, color $10.9 \mathrm{PCU}$, BOD $51 \mathrm{mg} / \mathrm{L}$, TDS $1080.25 \mathrm{mg} / \mathrm{L}$ and BOD/COD 0.45 were found. After the treatment of the effluent under optimum conditions, it also fulfilled the discharge norms, as shown in Table 4.

Table 4

Effluent discharge norms and characteristics of effluent treated under optimum conditions ${ }^{3}$

\begin{tabular}{lcc}
\hline Parameter & Discharge range & After treatment \\
\hline $\mathrm{pH}$ & $5.5-8.5$ & $6.8-7.6$ \\
$\mathrm{TSS}, \mathrm{mg} / \mathrm{L}$ & 50 & 37.23 \\
$\mathrm{TDS}, \mathrm{mg} / \mathrm{L}$ & 2100 & 1080.25 \\
$\mathrm{COD}, \mathrm{mg} / \mathrm{L}$ & 250 & 114 \\
$\mathrm{BDI}$ & $\mathrm{NA}$ & 0.45 \\
Color, $\mathrm{PCU}$ & Not defined & 10.9 \\
\hline
\end{tabular}




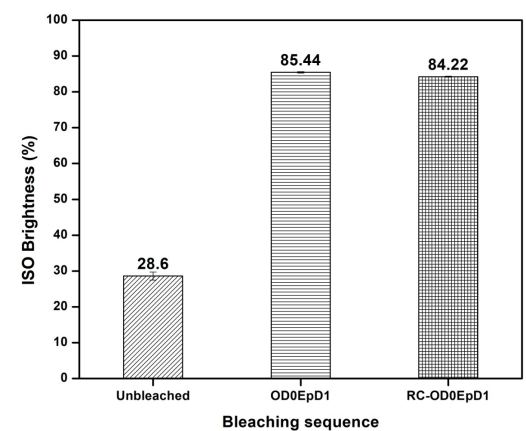

Figure 6: ISO brightness in $\mathrm{OD}_{0} \mathrm{E}_{\mathrm{p}} \mathrm{D}_{1}$ and RC$\mathrm{OD}_{0} \mathrm{E}_{\mathrm{p}} \mathrm{D}_{1}$ bleaching sequence

\section{Recycling of electrocoagulation treated effluent} for the assessment of paper properties

Treated effluent was then used for washing pulp in the same sequences represented by RC$\mathrm{OD}_{0} \mathrm{E}_{\mathrm{p}} \mathrm{D}_{1}$ and $\mathrm{RC}-\mathrm{D}_{0} \mathrm{E}_{\mathrm{p}} \mathrm{D}_{1}$. The effect of using recycled effluent on the optical properties brightness, as well as mechanical properties of the paper was determined.

\section{Brightness}

An optical photometer was used to measure the reflection at $457 \mathrm{~nm}$. For the same dosing of chemicals, the final ISO brightness was found to be 85.44 and $84.22 \%$ for $\mathrm{OD}_{0} \mathrm{E}_{\mathrm{p}} \mathrm{D}_{1}$ and RC$\mathrm{OD}_{0} \mathrm{E}_{\mathrm{p}} \mathrm{D}_{1}$ sequences, respectively. Similarly, ISO brightness 83.89 and $82.12 \%$ were measured for $\mathrm{D}_{0} \mathrm{E}_{\mathrm{p}} \mathrm{D}_{1}$ and $\mathrm{RC}-\mathrm{D}_{0} \mathrm{E}_{\mathrm{p}} \mathrm{D}_{1}$ sequences, respectively. As shown in Figures 6 and 7, reductions of 1.43\% and $2.11 \%$ in ISO brightness were recorded for $\mathrm{OD}_{0} \mathrm{E}_{\mathrm{p}} \mathrm{D}_{1}$ and $\mathrm{D}_{0} \mathrm{E}_{\mathrm{p}} \mathrm{D}_{1}$ sequences, respectively, because of COD and color. ${ }^{48,49}$

\section{Strength properties}

Bleached pulp from all the four different stages was beaten to $40{ }^{\circ} \mathrm{SR}$ to get good

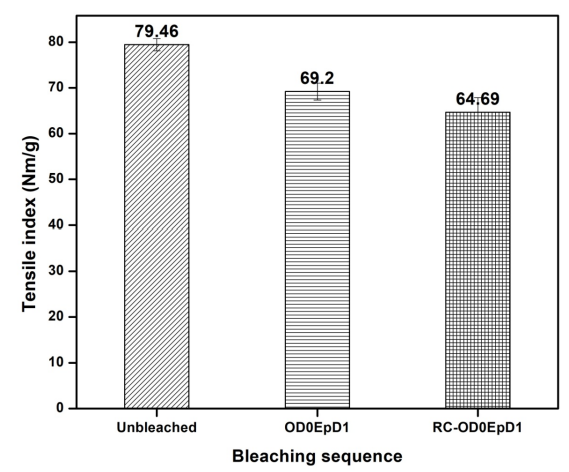

Figure 8: Tensile index in $\mathrm{OD}_{0} \mathrm{E}_{\mathrm{p}} \mathrm{D}_{1}$ and $\mathrm{RC}-\mathrm{OD}_{0} \mathrm{E}_{\mathrm{p}} \mathrm{D}_{1}$ bleaching sequence

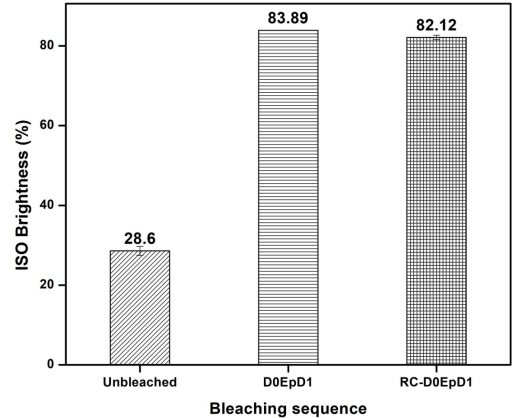

Figure 7: ISO brightness in $\mathrm{D}_{0} \mathrm{E}_{\mathrm{p}} \mathrm{D}_{1}$ and RC- $\mathrm{D}_{0} \mathrm{E}_{\mathrm{p}} \mathrm{D}_{1}$ bleaching sequence

runnability on the machine. ${ }^{50}$ Thereafter, this pulp was used for the preparation of handsheets, which were then tested for various mechanical properties, such as tensile index, tear index, burst index, and double-fold. We found insignificant differences in the results. For the $\mathrm{OD}_{0} \mathrm{E}_{\mathrm{p}} \mathrm{D}_{1}$ sequence, we found the following values of mechanical properties: tensile index $69.2 \mathrm{Nm} / \mathrm{g}$, tear index $7.16 \mathrm{mNm}^{2} / \mathrm{g}$, burst index 6.35 $\mathrm{kPam}^{2} / \mathrm{g}$, and double fold 79 . For the RC$\mathrm{OD}_{0} \mathrm{E}_{\mathrm{p}} \mathrm{D}_{1}$ sequence, the corresponding values declined slightly: tensile index $64.69 \mathrm{Nm} / \mathrm{g}$, tear index $6.73 \mathrm{mNm}^{2} / \mathrm{g}$, burst index $6.11 \mathrm{kPam}^{2} / \mathrm{g}$, and double fold 74. For the $\mathrm{D}_{0} \mathrm{E}_{\mathrm{p}} \mathrm{D}_{1}$ sequence, the following results were recorded: tensile index $74.69 \mathrm{Nm} / \mathrm{g}$, tear index $7.40 \mathrm{mNm}^{2} / \mathrm{g}$, burst index $6.85 \mathrm{kPam}^{2} / \mathrm{g}$, and double fold 124 . Meanwhile, for the RC- $\mathrm{D}_{0} \mathrm{E}_{\mathrm{p}} \mathrm{D}_{1}$ sequence, we found close values: tensile index $71.82 \mathrm{Nm} / \mathrm{g}$, tear index 7.32 $\mathrm{mNm}^{2} / \mathrm{g}$, burst index $6.62 \mathrm{kPam}^{2} / \mathrm{g}$, and double fold 119. These results are illustrated in Figures 8 to 15 , clearly indicating the efficient removal of pollutants and impurities, which hinder fiber bonding.

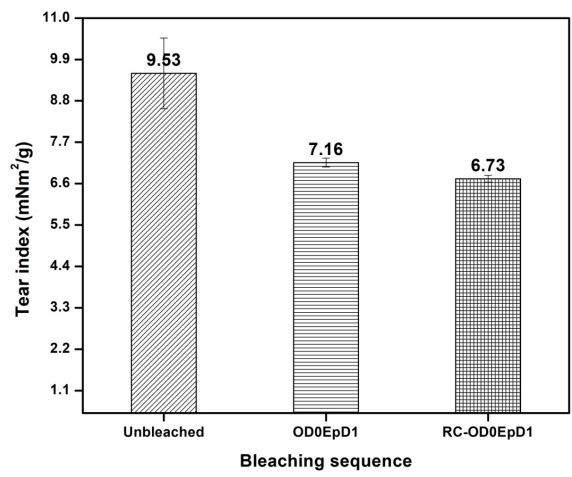

Figure 9: Tear index in $\mathrm{OD}_{0} \mathrm{E}_{\mathrm{p}} \mathrm{D}_{1}$ and $\mathrm{RC}-\mathrm{OD}_{0} \mathrm{E}_{\mathrm{p}} \mathrm{D}_{1}$ bleaching sequence 


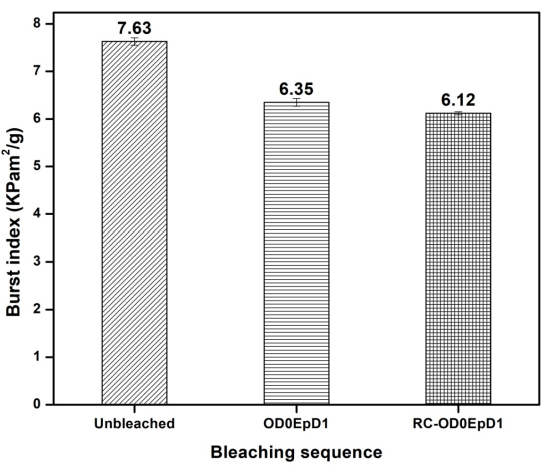

Figure 10: Burst index in $\mathrm{OD}_{0} \mathrm{E}_{\mathrm{p}} \mathrm{D}_{1}$ and RC- $\mathrm{OD}_{0} \mathrm{E}_{\mathrm{p}} \mathrm{D}_{1}$ bleaching sequence

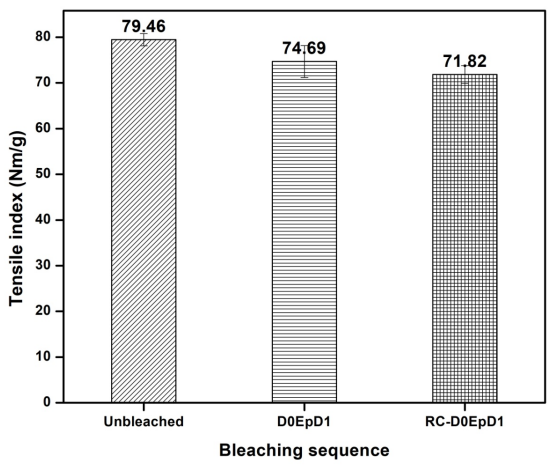

Figure 12: Tensile index in $\mathrm{D}_{0} \mathrm{E}_{\mathrm{p}} \mathrm{D}_{1}$ and $\mathrm{RC}-\mathrm{D}_{0} \mathrm{E}_{\mathrm{p}} \mathrm{D}_{1}$ bleaching sequence

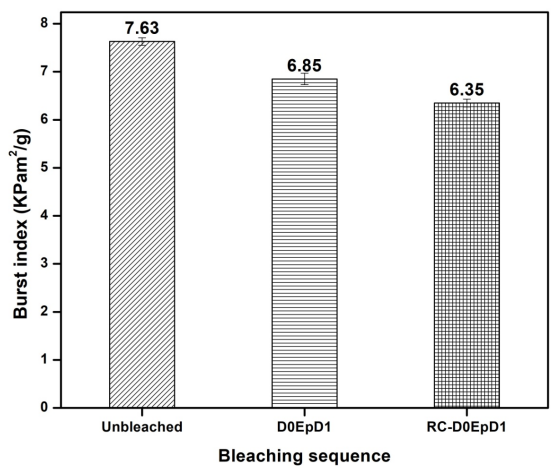

Figure 14: Burst index in $\mathrm{D}_{0} \mathrm{E}_{\mathrm{p}} \mathrm{D}_{1}$ and $\mathrm{RC}-\mathrm{D}_{0} \mathrm{E}_{\mathrm{p}} \mathrm{D}_{1}$ bleaching sequence

\section{CONCLUSION}

It was observed that the electrocoagulation method provided encouraging results in degrading organic pollutants from effluent water. It increased the biodegradability index by the removal of organic compounds. Treated water can reduce the requirement of fresh water through recycling during pulp washing stages in bleaching. No significant reduction has been

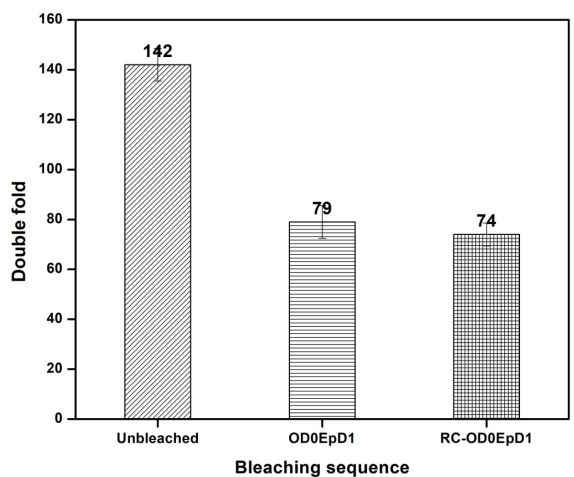

Figure 11: Double fold in $\mathrm{OD}_{0} \mathrm{E}_{\mathrm{p}} \mathrm{D}_{1}$ and RC- $\mathrm{OD}_{0} \mathrm{E}_{\mathrm{p}} \mathrm{D}_{1}$ bleaching sequence

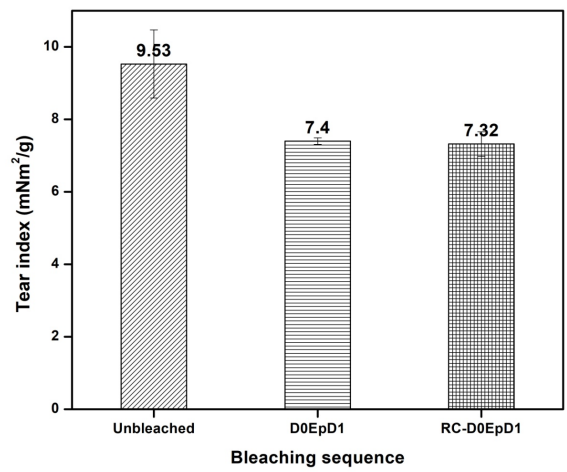

Figure 13: Tear index in $\mathrm{D}_{0} \mathrm{E}_{\mathrm{p}} \mathrm{D}_{1}$ and RC- $\mathrm{D}_{0} \mathrm{E}_{\mathrm{p}} \mathrm{D}_{1}$ bleaching sequence

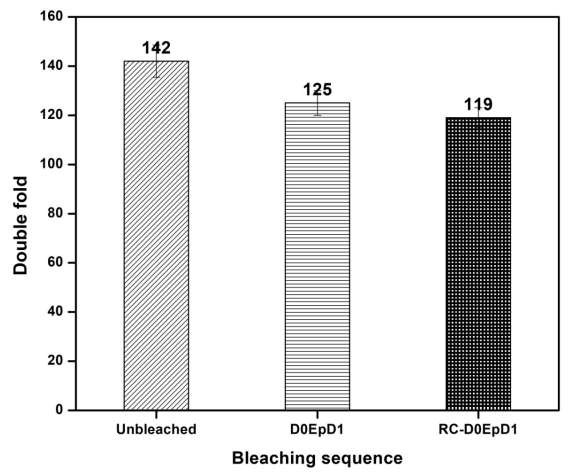

Figure 15: Double fold in $\mathrm{D}_{0} \mathrm{E}_{\mathrm{p}} \mathrm{D}_{1}$ and RC- $\mathrm{D}_{0} \mathrm{E}_{\mathrm{p}} \mathrm{D}_{1}$ bleaching sequence

found in the strength properties of the prepared paper, as caused by the recycling of treated effluent. A brightness reduction of $2.11 \%$ $\left(\mathrm{D}_{0} \mathrm{E}_{\mathrm{p}} \mathrm{D}_{1}\right)$ and $1.43 \%\left(\mathrm{OD}_{0} \mathrm{E}_{\mathrm{p}} \mathrm{D}_{1}\right)$ was found, but the reached brightness levels still satisfied ISO standards.

ACKNOWLEDGEMENT: This work was supported by the Ministry of Human Resource 
Development (MHRD), Government of India. The authors are highly grateful to IIT Roorkee, Saharanpur Campus, for providing the instrumental support for this study.

\section{REFERENCES}

1 A. K. Vidyarthi, D. Dutt and J. S. Upadhyaya, Cellulose Chem. Technol., 45, 291 (2011), https://cellulosechemtechnol.ro/pdf/CCT34(2011)/p.291-296.pdf

2 A. Izadi, M. Hosseini, G. N. Darzi, G. N. Bidhendi and F. P. Shariati, J. Environ. Health Sci. Eng., 16, 257 (2018),

https://link.springer.com/article/10.1007/s40201-0180314-6

3 R. Sridhar, V. Sivakumar, V. P. Immanuel and J. P. Maran, J. Hazard. Mater., 186, 1495 (2011), https://doi.org/10.1016/j.jhazmat.2010.12.028

4 R. K. Jain, "Compendium of Census Survey of Indian Paper Industry", 2015, http://www.cppri.org.in:80/img/compendium.pdf

5 P. M. Ansari, in Indo-EU Workshop on Promoting Efficient Use in Agro Based Industries, New Delhi, 2004, pp. $15-16$

6 M. Mousazadeh, E. K. Niaragh, M. Usman, S. U. Khan, M. A. Sandoval et al., Environ. Sci. Pollut. Res., 28, 43143 (2021), https://link.springer.com/article/10.1007/s11356-02114631-w

7 G. Thompson, J. Swain, M. Kay and C. F. Forster, Bioresour. Technol., 77, $275 \quad$ (2001), https://doi.org/10.1016/S0960-8524(00)00060-2

8 M. Vepsalainen, H. Kivisaari, M. Pulliainen, A. Oikari and M. Sillanpaa, Separ. Purif. Technol., 81, 141 (2011), https://doi.org/10.1016/j.seppur.2011.07.017

9 D. Mboowa, Biomass Convers. Biorefin., (2021), https://link.springer.com/article/10.1007/s13399-02001243-6

10 W. A. Laftah and W. A. W. A. Rahman, J. Nat. Fiber., $\quad \mathbf{1 3}, \quad 85 \quad$ (2016), https://www.tandfonline.com/doi/full/10.1080/154404 78.2014.984060

11 C. W. Dence, "Pulp Bleaching: Principles and Practice", TAPPI, Atlanta, Georgia, 1996

12 K. Ahn, S. Zaccaron, N. S. Zwirchmayr, H. Hettegger, A. Hofinger et al., Cellulose, 26, 429 (2019),

https://link.springer.com/article/10.1007/s10570-0182200-X

13 A. Gaspar, D. V. Evtuguin and C. P. Neto, Appl. Catal. $\quad A, \quad$ 239, $157 \quad$ (2003), https://doi.org/10.1016/S0926-860X(02)00378-2

14 K. S. Rajesh, M. Singaravel, P. Sankaralingam, S. Subramanian and S. V. Subrahmanyam, IPPTA, 21, 143 (2009)
15 D. Pokhrel and T. Viraraghavan, Sci. Total Environ., $\quad 333, \quad 37 \quad$ (2004), https://doi.org/10.1016/j.scitotenv.2004.05.017

16 A. Shahedi, A. K. Darban, F. Taghipour and A. J. Zanjani, Curr. Opin. Electrochem., 22, 154 (2020), https://doi.org/10.1016/j.coelec.2020.05.009

17 E. C. L. Coimbra, A. H. Mounteer, A. L. V. D. Carmo, M. J. F. Michielsen, L. A. Totola et al., Process Saf. Environ. Protect., 147, 346 (2021), https://doi.org/10.1016/j.psep.2020.09.039

18 T. Kreetachat, M. Damrongsri, V. Punsuwon, P. Vaithanomsat, C. Chiemchaisri et al., J. Hazard. Mater., $\quad \mathbf{1 4 2}, \quad 250 \quad$ (2007), https://doi.org/10.1016/j.jhazmat.2006.08.011

19 F. Potucek and M. Rihova, Cellulose Chem. Technol., $\quad 51, \quad 871 \quad$ (2017), https://www.cellulosechemtechnol.ro/pdf/CCT910(2017)/p.871-877.pdf

20 P. Bajpai, "Environmentally Benign Approaches for Pulp Bleaching", Elsevier, 2012, p. 263, https://doi.org/10.1016/B978-0-444-59421-1.00011-9.

21 S. Mahesh, B. Prasad, I. D. Mall and I. M. Mishra, Ind. Eng. Chem. Res., 45, 2830 (2006), https://doi.org/10.1021/ie0514096

22 M. Ugurlu, A. Gurses, C. Dogar and M. Yalcin, $J$. Environ. Manag., 87, $420 \quad$ (2008), https://doi.org/10.1016/j.jenvman.2007.01.007

${ }_{23}$ M. Kobya, O. T. Can and M. Bayramoglu, J. Hazard. Mater., 100, 163 (2003), https://doi.org/10.1016/S0304-3894(03)00102-X

24 N. Daneshvar, A. Oladegaragoze and N. Djafarzadeh, J. Hazard. Mater., 129, 116 (2006), https://doi.org/10.1016/j.jhazmat.2005.08.033

25 S. Vasudevan, G. Sozhan, S. Ravichandran, J. Jayaraj, J. Lakshmi et al., Ind. Eng. Chem. Res., 47, 2018 (2008), https://doi.org/10.1021/ie0714652

26 M. Y. A. Mollah, R. Schennach, J. R. Parga and D. L. Cocke, J. Hazard. Mater., 84, 29 (2001), https://doi.org/10.1016/S0304-3894(01)00176-5

27 P. Bajpai, A. Mehna and P. K. Bajpai, Process Biochem., 28, $\quad 377$ (1993) https://doi.org/10.1016/0032-9592(93)80024-B

28 E. W. Rice, R. B. Baird and A. D. Eaton, "Standard Methods for the Examination of Water and Wastewater", 2017, p. 23, https://doi.org/10.2105/SMWW.2882.002

${ }^{29}$ TAPPI T $205 \mathrm{sp}-02$, Forming handsheets for physical tests of pulp, (2006), https://www.tappi.org/content/sarg/t205.pdf

30 TAPPI T 248 sp-00, Laboratory beating of pulp (PFI mill method), (2000), https://canvas.umn.edu/courses/97076/files/5076978/pr eview

31 TAPPI T 236 om-99, Kappa number of pulp, (1999),

https://research.cnr.ncsu.edu/wpsanalytical/documents/ T236.PDF 
32 TAPPI T 227 om-94, Freeness of pulp (Canadian standard method), (1994), http://grayhall.co.uk/BeloitResearch/tappi/t227.pdf

33 TAPPI T 403 om-97, Bursting strength of paper, (1997), http://grayhall.co.uk/BeloitResearch/tappi/t403.pdf 34 TAPPI T 511 om-08, Folding endurance of paper (MIT tester), (2013),

https://www.tappi.org/content/tag/sarg/t511.pdf

35 TAPPI T 414 om-98, Internal tearing resistance of paper (Elmendorf-type method), (1998), http://grayhall.co.uk/BeloitResearch/tappi/t414.pdf

36 M. A. Zazouli and M. Taghavi, J. Water Resour. $\begin{array}{llll}\text { Prot., } & \text { 4, } & 980 & \text { (2012), }\end{array}$ http://dx.doi.org/10.4236/jwarp.2012.411113

37 S. Khansorthong and M. Hunsom, Chem. Eng. J., 151, 228

(2009), https://doi.org/10.1016/j.cej.2009.02.038

38 M. Y. A. Mollah, P. Morkovsky, J. A. G. Gomes, M. Kesmez, J. Parga et al., J. Hazard. Mater., 114, 199 (2004), https://doi.org/10.1016/j.jhazmat.2004.08.009

39 F. W. Gilcreas, Am. J. Public Health Nations Health, 56, $387 \quad$ (1966), https://dx.doi.org/10.2105\%2Fajph.56.3.387

40 M. Kobya, E. Demirbas, O. T. Can and M. Bayramoglu, J. Hazard. Mater., 132, 183 (2006), https://doi.org/10.1016/j.jhazmat.2005.07.084

41 N. Adhoum and L. Monser, Chem. Eng. Process., 43, 1281

(2004), https://doi.org/10.1016/j.cep.2003.12.001

42 G. Chen, X. Chen and P. L. Yue, J. Environ. Eng., 126, 858 (2000), https://doi.org/10.1061/(ASCE)07339372(2000)126:9(858)

43 N. K. Khosla, S. Venkatachalam and P. Somasundaran, J. Appl. Electrochem., 21, 986 (1991), https://link.springer.com/article/10.1007/BF01077584
44 P. K. Holt, G. W. Barton, M. Wark and C. A. Mitchell, Colloid. Surfaces A, 211, 233 (2002), https://doi.org/10.1016/S0927-7757(02)00285-6

45 N. Adhoum, L. Monser, N. Bellakhal and J. E. Belgaied, J. Hazard. Mater., 112, 207 (2004), https://doi.org/10.1016/j.jhazmat.2004.04.018

46 P. Manisankar, C. Rani and S. Viswanathan, Chemosphere, 57, 961 (2004), https://doi.org/10.1016/j.chemosphere.2004.07.026

47 A. S. Koparal and U. B. Ogutveren, J. Hazard. Mater., 89, 83 (2002), https://doi.org/10.1016/S03043894(01)00301-6

48 S. C. Stratton and P. Gleadow, "Pulp Mill Process Closure: A Review of Global Technology Developments and Mill Experiences in the 1990s", Technical Bulletin No. 860, May 2003, https://www.ncasi.org/wpcontent/uploads/2019/02/tb860.pdf

49 N. Jemaa, R. Thompson, M. Paleologou and R. M. Berry, Pulp Pap. Can., 101, 41 (2000)

50 A. R. K. Rao, G. Srinivasan and H. K. Maheshwari, Indian Pulp Pap., 35 (1978), https://agris.fao.org/agrissearch/search.do?recordID=US201302432509 